\title{
MANGANOAN ILMENITE FROM THE SÄVIÄ ORE DEPOSIT, PIELAVESI, CENTRAL FINLAND
}

\author{
LEA AHO
}

\begin{abstract}
AHO, LEA 1977: Manganoan ilmenite from the Säviä ore deposit, Pielavesi, Central Finland. Bull. Geol. Soc. Finland 49: 25-31.

Electron microprobe analyses of nine ilmenites from a sulphide ore deposit at Säviä, Pielavesi are given. For comparison, two ilmenite analyses, one from an ore erratic and one from Säviä schists, are included. The MnO content of the ilmenites from the sulphide ore is as much as $16.6 \mathrm{wt}$. per cent. The manganoan ilmenite forms a myrmekitic intergrowth with sulphide minerals. Associated minerals are magnetite ( 0.3 wt. per cent $\left.\mathrm{TiO}_{2}\right)$, cassiterite, ferroan gahnite (54.3 mole per cent $\mathrm{ZnAl}_{2} \mathrm{O}_{4}$ ) and garnet (30.6 mole per cent spessartine). The enrichment of Mn in ilmenite is assumed to be caused by hydrothermal activity during the formation of the Säviä ore.
\end{abstract}

Lea Aho, Geological Survey of Finland, SF-02150 Espoo 15, Finland

\section{Introduction}

The discovery of two chalcopyrite-bearing ore erratics in the Pielavesi area led the Exploration Department of the Geological Survey of Finland to investigate the area in 1960 -1964. Minor ilmenite and garnet rich in manganese were observed besides the main ore minerals chalcopyrite, pyrrhotite, pyrite and sphalerite.

A copper-zinc ore body in the village of Säviä (lat. $63^{\circ} 12^{\prime} 30^{\prime \prime} \mathrm{N}$, long. $26^{\circ} 40^{\prime} 20^{\prime \prime} \mathrm{E}$ ), Pielavesi, which has not been submitted to mining activities, was discovered by drilling in 1966-1968. The same mineral assemblage with manganese-bearing minerals was found in the ore body as had been found in the erratics. The unusually high manganese con- tent and the peculiar, myrmekitic texture of the ilmenite intrigued the author into making a more detailed study of this mineral.

Previous investigations of manganese occurrences in Finland have not shown manganese-rich ilmenite or pyrophanite. Laitakari (1967) has mentioned one pyrophanite occurrence from Joensuu. Re-investigation of the original material using an electron microanalyser revealed that the mineral is common ilmenite with a low manganese content from 1 to 2 per cent $\mathrm{MnO}$.

\section{General geology}

The schist belt at Säviä is part of the crystalline schist suite of the Pielavesi district described by Wilkman (1938). The schists 
are conspicuously banded and veined migmatitic rocks, mainly of supracrustal origin.

In an unpublished report, Laitakari (1968) has given a comprehensive description of the Säviä schists, largely based on material collected during exploration. The schists consist mainly of cordierite-anthophyllite gneiss, hornblende-cummigtonite gneiss and amphibolite with considerable abundances of alumina-rich minerals, e.g. garnet and sillimanite. The ore body lies within a fracture zone which is roughly concordant with the bedding, but also clearly cuts across the schists. The beds strike approximately from $\mathrm{N}$ to $\mathrm{S}$, and dip from $40^{\circ}$ to $70^{\circ} \mathrm{E}$.

\section{Mineral description}

The oxide ore minerals in the Säviä ore body are magnetite, ilmenite and a minute amount of cassiterite. They occur either as rounded discrete grains or as dense irregular aggregates or nodules with garnet and spinel. The associated accessories are biotite, chlorite, anthophyllite, cordierite, sillimanite and sulphides. The aggregates vary in size between 2 to $5 \mathrm{~cm}$ and can clearly be detected in the quartz and sulphide ore matrix.

Electron microprobe analysis (Table 1.) revealed the garnet to be an almandine-spessartine. The scanning image of $\mathrm{Mn}$ shows no sign of the compositional zoning that is common in metamorphic garnet. The $\mathrm{MnO}$ content of garnet generally decreases with increasing metamorphic grade. Since $\mathrm{Mn}^{+2}$ ions are the most appropriate in size for entering the crystal structure of Ca-poor garnet, only garnet rich in $\mathrm{Mn}^{+2}$ can be formed at very low temperatures (Miyashiro 1953).

Spinel is green in colour and varies in grain size from $0.02 \mathrm{~mm}$ to $2 \mathrm{~mm}$. The spinel grains contain small zonally arranged exsolution bodies of magnetite and numerous inclusions of pyrrhotite, chalcopyrite, galena and ilmenite. Microprobe analysis proved the spinel to be a ferroan gahnite (Table 2).

Table 2. A microprobe analysis for ferroan gahnite from Säviä ore. Anal. T. Paasivirta

\begin{tabular}{|c|c|c|c|c|}
\hline & $\begin{array}{l}\text { Wt. per } \\
\text { cent }\end{array}$ & $\begin{array}{l}\text { Number of ions } \\
\text { based on } 24(\mathrm{O})\end{array}$ & \multicolumn{2}{|c|}{$\begin{array}{l}\text { Mol. per cent } \\
\text { end-members }\end{array}$} \\
\hline $\mathrm{Al}_{2} \mathrm{O}_{3}$ & 57.8 & \multirow{5}{*}{$\left.\begin{array}{lr}\mathrm{Al} & 16.04 \\
\mathrm{Fe}^{2+} & 2.75 \\
\mathrm{Mg} & 1.15 \\
\mathrm{Zn} & 4.03\end{array}\right\}^{7.93}$} & \multirow{5}{*}{$\begin{array}{l}\mathrm{ZnAl}_{2} \mathrm{O}_{4} \\
\mathrm{MgAl}_{2} \mathrm{O}_{4} \\
\mathrm{FeAl}_{2} \mathrm{O}_{4} \\
\left(\mathrm{Al}_{2} \mathrm{O}_{3}\right.\end{array}$} & 54.3 \\
\hline $\mathrm{FeO}$ & 14.0 & & & 11.6 \\
\hline $\mathrm{MgO}$ & 3.3 & & & 33.8 \\
\hline $\mathrm{ZnO}$ & 25.3 & & & \multirow[t]{2}{*}{0.3 ) } \\
\hline & 100.4 & & & \\
\hline
\end{tabular}

\section{Magnetite}

The main oxide ore mineral in the Säviä ore is magnetite, which occurs as discrete grains or as rims around the sulphide grains.

Table 1. A microprobe analysis for garnet from Säviä ore. Anal. T. Paasivirta

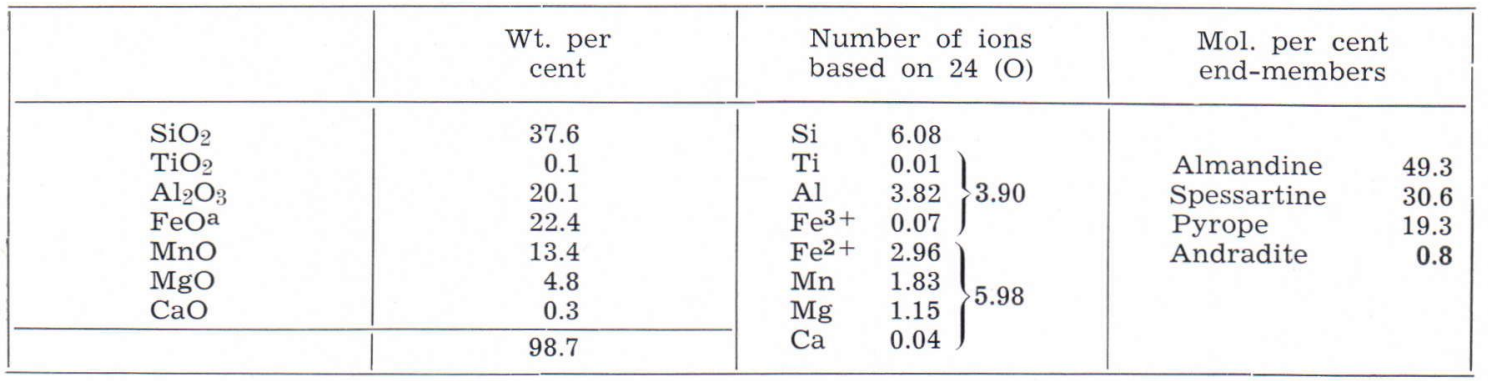

a Total iron expressed as $\mathrm{FeO}$ 
A few minute exsolution blebs of spinel and some thin ilmenite lamellae $(0.02 \mathrm{~mm})$ are found within the magnetite grains. The thin ilmenite lamellae remaining within magnetite are considered to reflect later stage oxidation at very low temperatures (Vincent 1960).

Table 3. Average of seven microprobe analyses and calculated normative components for magnetite grains from Säviä ore. Anal. T. Paasivirta

\begin{tabular}{|l|r|lr|}
\hline & $\begin{array}{c}\text { Wt. per } \\
\text { cent }\end{array}$ & \multicolumn{2}{|c|}{$\begin{array}{c}\text { Normative components } \\
\text { per cent }\end{array}$} \\
\hline $\mathrm{TiO}_{2}$ & 0.3 & $\mathrm{Mn}_{2} \mathrm{TiO}_{4}$ & 0.1 \\
$\mathrm{Al}_{2} \mathrm{O}_{3}$ & 0.3 & $\mathrm{Fe}_{2} \mathrm{TiO}_{4}$ & 0.3 \\
$\mathrm{FeO}$ & 30.5 & $\mathrm{Fe}_{3} \mathrm{O}_{4}$ & 97.5 \\
$\mathrm{Fe} \mathrm{O}_{3}$ & 67.3 & $\mathrm{Total} \mathrm{R}_{3} \mathrm{O}_{4}$ & 98.4 \\
$\mathrm{MnO}$ & 0.1 & $\mathrm{Fe}_{2} \mathrm{TiO}_{4} \mathrm{~b}$ & \\
$\mathrm{MgO}$ & 0.2 & $\mathrm{Fe}_{2} \mathrm{TiO}_{4}+\mathrm{Fe}_{3} \mathrm{O}_{4}$ & 0.3 \\
\hline
\end{tabular}

a $\mathrm{FeO} / \mathrm{Fe}_{2} \mathrm{O}_{3}$ assumed ideal for magnetite.

b Ratio expressed as $100 x$ mole ratio of components. (Anderson 1968)

The microprobe analyses (Table 3 ) indicated a low titanium content for the magnetites ( 0.2 to 0.5 wt. per cent $\mathrm{TiO}_{2}$ ). A low titanium content $\left(0.3\right.$ wt. per cent $\mathrm{TiO}_{2}$ ) was also noted for magnetite from the Säviä schists in one analysis. The $\mathrm{TiO}_{2}$ content of magnetite varies with the metamorphic grade of the rock, and may be used as a general temperature indicator (Buddington et al. 1955). Magnetite formed at low grade metamorphic temperatures and pressures is nearly pure $\mathrm{Fe}_{3} \mathrm{O}_{4}(\mathrm{Ab}-$ dullah and Atherton 1964).

\section{Ilmenite}

Two texturally different types of ilmenite, primary and secondary, can be distinguished in the Säviä ore.

The primary ilmenite occurs as discrete grains, grain size 0.3 to $0.5 \mathrm{~mm}$, and interstitial to the silicates (mostly quartz). It appears to occur independently of magnetite, but may form aggregates with it. This ilmenite contains minute lamellae of exsolved hematite orientated parallel to (0001) of the host ilmenite. Small corundum grains are found as exsolution products within the ilmenite. Ramdohr (1969) concluded that some ilmenite originating from ore differentiates very rich in $\mathrm{Al}_{2} \mathrm{O}_{3}$ may contain corundum grains.

The secondary ilmenite, the sexsolved ilmenite», forms with magnetite four texturally different types of intergrowth: 1) coarse subhedral plates (grain size up to 0.3 to $1 \mathrm{~mm}$ ) which contain minute lamellae of exsolved hematite (Fig. 1), 2) internal granular grains (Fig. 2), 3) thin magnetite lamellae and 4) myrmekitic intergrowth. The lamellar and myrmekitic intergrowths are clearly seen in Fig. 1. The textural types 2 to 4 ) of the ilmenite-magnetite intergrowth do not contain hematite as exsolution blebs.

Removal by solution of the magnetite component from textural type 3) can produce

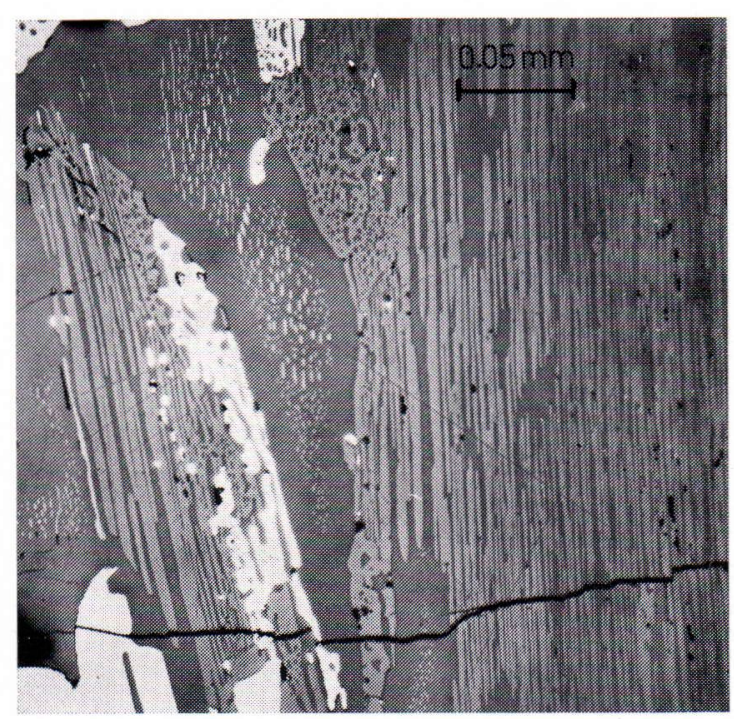

Fig. 1 Lamellar and myrmekitic intergrowth between ilmenite (dark grey) and magnetite (grey), and pyrrhotite (white). In the middle of the photomicrograph ilmenite (dark grey) with exsolution blebs of hematite (grey). 


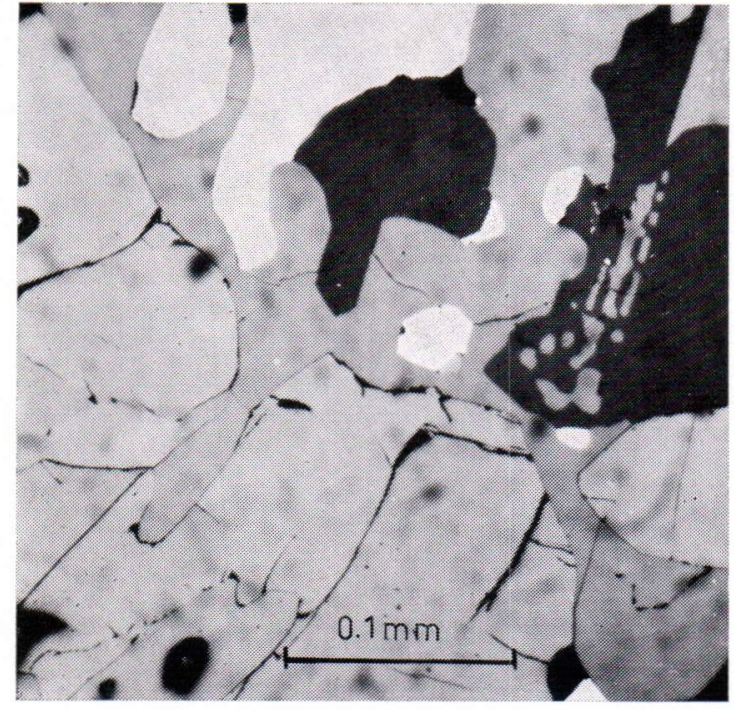

Fig. 2 Granular intergrowth between magnetite (light grey) and ilmenite (grey). Cassiterite (black) myrmekitic intergrowth with ilmenite. White grains are pyrite.

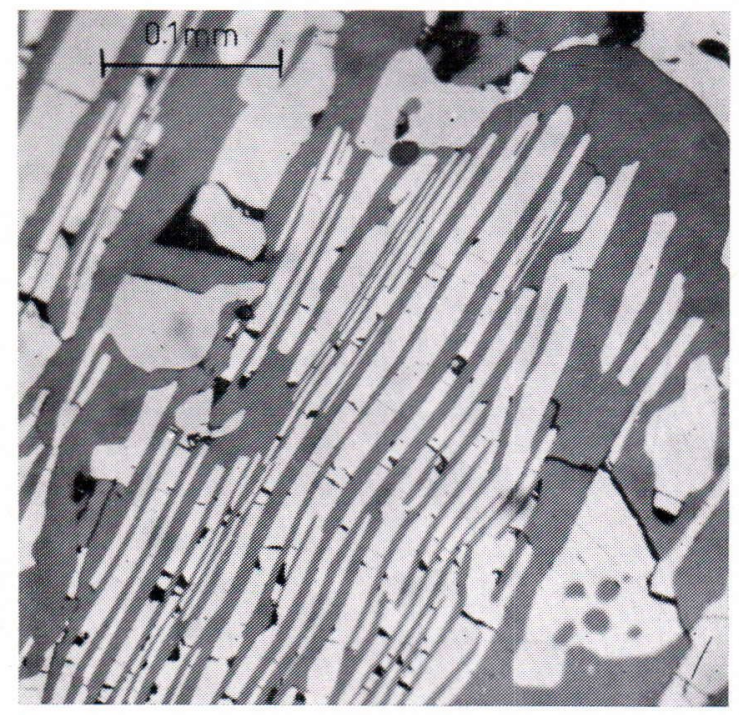

Fig. 3 Lamellar pyrrhotite and chalcopyrite (light grey) within ilmenite (dark grey).

skeletal ilmenite grains. The magnetite removed is replaced by silicate minerals.

A peculiar lamellar and myrmekitic intergrowth occurs between secondary ilmenite, and sulphides such as pyrrhotite, chalcopy-

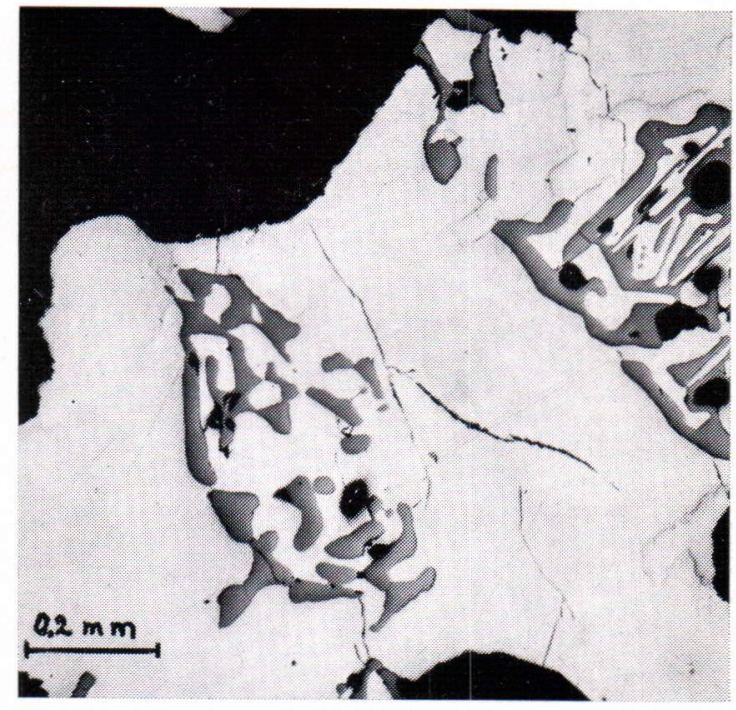

Fig. 4 Ilmenite (dark grey) partly replaced by chalcopyrite (white). Slightly harder pyrrhotite grains (white) within the chalcopyrite.

rite, cubanite, pyrite, galena and sphalerite. This sulphide texture within an ilmenite is caused by the replacement of the magnetite component of the ilmenite-magnetite intergrowth by sulphides (Figs. 1 and 3). They commonly replace magnetite more readily than ilmenite, and they may also partly replace ilmenite, although this mineral is very resistant (Fig. 4).

Cassiterite forms a myrmekitic intergrowth with the secondary ilmenite (Fig. 2). Exsolved cassiterite in magnetite or ilmenite has been described by Desborough and Sainsbury (1970). It is possible that also in the Säviä ore, tin originally occurred as solid solution in magnetite and was remobilized during latestage alteration, accompanied by the introduction of sulphide minerals.

\section{Investigation of ilmenite by electron microprobe}

The data were obtained using a Geoscan electron probe microanalyser with an accelerating potential of $20 \mathrm{kV}$ and $0.1 \mu \mathrm{A}$ specimen 
current. Chemically analysed ilmenite served as standard, and manganese was measured using pure element. Raw data were corrected applying the method described by Bence and Albee (1968). No attempt was made to determine directly the oxydation states of $\mathrm{Fe}$ and Mn. In several of the grains investigation by microprobe was prevented by the fine set of magnetite lamellae or the exsolution blebs of hematite in ilmenite.

The results of the microprobe analyses are given in Table 4. The ilmenites chosen for the measurement are from the drill cores of the Säviä ore body except for samples No. 8891, an ilmenite from ore erratic II, and No. 7044, an ilmenite from the Säviä schists.

The most important finding of the investigation is that the composition of primary ilmenite is obviously different from that of secondary ilmenite. Primary ilmenite (Table 4, No. 11112B) has lower Ti and Mn contents and a higher iron content (higher recalculated hematite content) than has secondary ilmenite, which is represented by the other ilmenites in Table 4. These results are in good agreement with the conclusion of Mathison (1975) that the differences in chemical composition allow a distinction to be made between grains of primary and secondary ilmenite, using the microprobe.

The highest $\mathrm{MnO}$ content in the secondary ilmenite is in those grains in which the magnetite component is replaced by sulphides. The manganoan ilmenite contains up to 35.2 mole per cent pyrophanite. There were ilmenite grains with only 0.8 per cent pyrophanite: No. 1111B, a skeletal ilmenite in which the magnetite component is replaced by silicates and No. 7044, an ilmenite with lamellar magnetite from the Säviä schists. Both of them seem to represent ilmenite of secondary origin. Thus, it appears that the highest manganese content in ilmenite at Säviä is connected with the aggregates of garnet, spinel and iron-titanium oxides within the sulphide ore.

\section{Discussion}

If coexisting magnetite and ilmenite crystallize in equilibrium, both the oxygen fugacity and temperature that prevail during crystallization can be estimated from the chemical compositions of the minerals by the experimental data of Buddington and Lindsley (1964).

The existence of compositional differences between primary and secondary ilmenite indicates that in the Säviä ore the equilibrium was not maintained for the Fe-Ti oxides during the crystallization (or recrystallization) sequence.

The textural relationships of the opaque oxide minerals in the Säviä ore were determined optically. Skeletal ilmenite is presumably formed by the removal of magnetite from the ilmenite-magnetite intergrowth. The lamellar and myrmekitic texture between ilmenite and sulphide minerals proves that the magnetite component of the ilmenitemagnetite intergrowth was removed and replaced by sulphides. In the light of their petrographic observations, Davidson and Wyllie (1968) have suggested that an aqueous fluid phase formed within crystallizing mag$\mathrm{ma}$ is capable of dissolving iron from titaniferous magnetite and leaving behind skeletal ilmenite. Such a movement of iron in an aqueous vapour phase has also been observed during hydrothermal melting experiments (Martin and Piwinskii 1969).

In his pyrophanite study, Žák (1971) has shown that such elements as titanium, manganese and iron can be extracted by hydrothermal solution from a tuffaceous sediment. Hydrothermal activity may also have occurred during the formation of the Säviä ore, and this could explain why the secondary ilmenites of the Säviä schists are not as rich in manganese as are those from the sulphide ore. 
Table 4. Microprobe analyses and calculated normative components for ilmenite-pyrophanite grains. Anal. T. Paasivirta

\begin{tabular}{|c|c|c|c|c|c|c|c|c|c|c|c|}
\hline Sample No. & 8891 & 9021 & 11109 & $11112 \mathrm{~A}$ & 9019 & $11111 \mathrm{~A}$ & 9022 & 9218 & $11112 \mathrm{~B}$ & $11111 \mathrm{~B}$ & 7044 \\
\hline $\mathrm{TiO}_{2}$ & 47.0 & 49.3 & 46.8 & 45.8 & 46.3 & 46.9 & 46.1 & 46.8 & 40.3 & 44.3 & 44.3 \\
\hline $\mathrm{FeO}^{\mathrm{a}}$ & 35.7 & 35.5 & 36.6 & 38.5 & 42.8 & 46.6 & 49.5 & 48.4 & 56.1 & 54.2 & 55.6 \\
\hline $\mathrm{MnO}$ & 16.6 & 14.7 & 14.7 & 12.5 & 10.3 & 5.5 & 5.2 & 4.7 & 2.1 & 0.4 & 0.4 \\
\hline $\mathrm{MgO}$ & 0.2 & 0.3 & 0.3 & 0.2 & 0.2 & 0.5 & 0.2 & 0.3 & 0.2 & 0.2 & 0.4 \\
\hline $\mathrm{Al}_{2} \mathrm{O}_{3}$ & 0.1 & 0.1 & 0.1 & 0.1 & 0.1 & 0.1 & 0.1 & 0.1 & 0.1 & 0.1 & 0.1 \\
\hline Total & 99.6 & 99.9 & 98.6 & 97.1 & 99.7 & 99.6 & 101.1 & 100.3 & 98.8 & 99.2 & 100.8 \\
\hline $\mathrm{MnTiO}_{3}$ & 35.2 & 31.2 & 31.2 & 26.5 & 21.7 & 11.6 & 11.0 & 9.9 & 4.4 & 0.8 & 0.8 \\
\hline $\mathrm{FeTiO}_{3}$ & 53.1 & 61.0 & 56.3 & 59.7 & 65.2 & 75.4 & 75.8 & 77.6 & 71.4 & 82.6 & 81.9 \\
\hline $\mathrm{Fe}_{2} \mathrm{O}_{3}$ & 10.5 & 6.5 & 9.9 & 10.2 & 11.8 & 10.8 & 13.5 & 11.5 & 22.2 & 15.0 & 16.6 \\
\hline $\mathrm{MgTiO}_{3}$ & 0.5 & 0.8 & 0.8 & 0.5 & 0.5 & 1.4 & 0.5 & 0.8 & 0.5 & 0.5 & 1.1 \\
\hline $\mathrm{Al}_{2} \mathrm{O}_{3}$ & 0.1 & 0.1 & 0.1 & 0.1 & 0.1 & 0.1 & 0.1 & 0.1 & 0.1 & 0.1 & 0.1 \\
\hline $\begin{array}{r}\text { Total } \mathrm{R}_{2} \mathrm{O}_{3} \\
\mathrm{Fe}_{2} \mathrm{O}_{3} \mathrm{~b}\end{array}$ & 99.4 & 99.6 & 98.3 & 97.0 & 99.3 & 99.3 & 100.8 & 99.9 & 98.6 & 99.0 & 100.5 \\
\hline$\overline{\mathrm{Fe}_{2} \mathrm{O}_{3}+\mathrm{FeTiO}_{3}}$ & 16.5 & 9.6 & 14.9 & 17.0 & 15.3 & 12.5 & 13.6 & 12.9 & 23.7 & 15.3 & 16.8 \\
\hline
\end{tabular}

All values except for ratios in weight per cent.

a All Fe calculated as $\mathrm{FeO}$ for ilmenite.

b Ratio expressed as $100 \mathrm{x}$ mole ratio of components. (Anderson 1968)

No.
8891
9021
11109
11112 A
9019
11111 A
9022
9218
11112 B
11111 B
7044

1) Drill hole No., depth in metres

\begin{abstract}
Sample code
ore erratic II

$\mathrm{R} 39 / 78.20 \mathrm{~m}^{1}$ )

$\mathrm{R} 87 / 529.20 \mathrm{~m}$

$\mathrm{R} 39 / 78.20 \mathrm{~m}$

$\mathrm{R} 39 / 55.40 \mathrm{~m}$

$\mathrm{R} 72 / 351.85 \mathrm{~m}$

$\mathrm{R} 39 / 80.30 \mathrm{~m}$

$\mathrm{R} 72 / 351.85 \mathrm{~m}$

$\mathrm{R} 39 / 78.20 \mathrm{~m}$

$\mathrm{R} 72 / 351.85 \mathrm{~m}$

R3 /64.13 m
\end{abstract}

Ilmenite texture

intergrowth with pyrrhotite

$$
\begin{aligned}
& \text { » chalcopyrite } \\
& \text { » pyrrhotite } \\
& \text { » chalcopyrite } \\
& \begin{array}{lll}
» & \text { pyrrhotite } \\
» & \text { chalcopyrite }
\end{array}
\end{aligned}
$$

granular

intergrowth with chalcopyrite

with exsolution blebs of hematite

skeletal

with lamellar magnetite 
Acknowledgements. I am indebted to Drs. I. Haapala and J. Siivola for their valuable criticism of the manuscript, and to Miss T. Paasivirta, M.Sc. for doing the microprobe analyses. My sin- cere thanks are also due to Mr. A. J. Laitakari, M.Sc. and Mr. P. Oivanen, M.Sc. who drew my attention to this subject during the prospecting of the Säviä ore deposit.

\section{References}

Abdullah, M. I. and Atherton, M. P. (1964) The thermometric significance of magnetite in low grade metamorphic rocks. Am. J. Sci. 262: $904-917$.

Anderson, A. T. (1968) Oxidation of the LaBlache Lake titaniferous magnetite deposit, Quebec. J. Geol. 76: 528-547.

Bence, A. E. and Albee, A. L. (1968) Empirical correction factors for electron microanalysis of silicates and oxides. J. Geol. 76: 382-403.

Buddington, A. F., Fahey, J. and Vlisidis, A. (1955) Thermometric and petrogenetic significance of titaniferous magnetite. Am. J. Sci. 253: 497532.

Buddington, A. F. and Lindsley, D. H. (1964) Irontitanium oxide minerals and synthetic equivalents. J. Petrol. 5: $310-357$.

Davidson, A. and Wyllie, P. J. (1968) Opaque oxide minerals of some diabase-granophyre associations in Pennsylvania. Econ. Geol. 63: $950-960$.

Desborough, G. A. and Sainsbury, C. L. (1970) Cassiterite as an exsolution product in magnetite, Lost River tin mine, Alaska. Econ. Geol. 65: 1004-1007.

Laitakari, A. (1967) Suomen mineraalien hake- misto (Index of Finnish minerals with bibliography). Bull. Comm. Géol. Finlande 230.

Laitakari, A. J. (1968) Säviän kuparimalmin geologiasta. Unpublished report. Geological Survey of Finland.

Martin, R. E. and Piwinskii, A. J. (1969) Experimental data bearing on the movement of iron in an aqueous vapor. Econ. Geol. 64: 798-803. Mathison, C. I. (1975) Magnetites and ilmenites in the Somerset Dam layered basic intrusion, southeastern Queensland. Lithos 8: 93-111.

Miyashiro, A. (1953) Calcium poor garnet in relation to metamorphism. Geochim.Cosmochim. Acta 4: 179-208.

Ramdohr, P. (1969) The ore minerals and their intergrowths. Pergamon Press. Braunschweig. Wilkman, W. W. (1938) Kivilajikartan selitys, lehti C 3, Kuopio. English summary: Explanation to the Map of Rocks. Suomen Geologinen Yleiskartta, 1: 400000.

Vincent, E. A. (1960) Ulvöspinel in the Skaergaard intrusion, Greenland. N. Jahrb. Min. Abh. 94: $993-1016$.

Zák, L. (1971) Pyrophanite from Chvaletice (Bohemia). Min. Mag. 38: 312-316.

Manuscript received, April 2, 1976. 